\title{
Facilitating Korean Reconciliation through Constitutional Law ${ }^{*}$
}

\author{
DAMIEN P. HORIGAN ${ }^{* *}$
}

This article looks at the so-called Korean Problem or Korean Question from a fresh perspective. Instead of advocating a quick yet costly reunification of Korea along German lines or any specific type of federation, confederation, or commonwealth, a new approach to both Korean reconciliation and possible reunification based on negotiated constitutional change, the symbolic power of constitutions, and the Habermasian concept of constitutional patriotism is proposed. Specifically, the example of the Northern Ireland peace process is presented as an alternative legal model that can be creatively applied to conditions on the Korean Peninsula.

Keywords: Divided Nations, Peace Process, Constitutional Law

This article draws on research done for my LLM thesis under the supervision of Dr. Victor V. Ramraj at the National University of Singapore. I am grateful for the comments received on the manuscript for this article from two anonymous referees from the International Studies Review. Likewise, I appreciate the earlier comments on my LLM thesis from the members of my committee. Naturally, however, I am responsible for the views expressed herein.

** Associate Professor, School of Business Administration, American University in Dubai. Post Office Box 28282, Dubai, United Arab Emirates. E-mail: dhorigan@aud.edu; Website: http://aud.edu/Academic-Programs/Business/bus-dhorigan.asp 


\section{INTRODUCTION}

$\mathrm{T}$ ies between North Korea, officially the Democratic People's Republic of Korea (DPRK), and South Korea, officially the Republic of Korea (ROK), remain a serious challenge more than half a century after the armistice agreement that effectively ended the Korean War (Lyou 1986). The relationship has featured a long stalemate, political crises, and periods of relative cooperation (M. Lee 1994; Moon and Steinberg 1999; E. Lee 2004; Olsen 2005). At the time of writing, a lasting peace treaty still has not been signed. Formal diplomatic relations between the two Koreas have never been established although both states joined the United Nations (UN) in 1991 (UN 2006). The top leaders have only met twice (South-North Joint Declaration 2000; Declaration on the Advancement of South-North Korean Relations, Peace and Prosperity 2007).

In this article I will examine the potential of constitutional law in facilitating Korean reconciliation and how the Northern Ireland Peace Process (Fearon and McWilliams 1999; O'Leary 1999; A. Morgan 2000; Wilford 2001; Anderson 2002; Powell 2008) could serve as a model for Korean reconciliation.

\section{WHY IRELAND?}

Ireland might not be an obvious choice. Admittedly, Korea and Ireland are different in many ways. Certainly, there are significant differences in terms of geography, culture, language, colonial heritage, legal tradition, political systems, levels of economic development, and the nature of the division itself. According to the methodological insights of Ran Hirschl into comparative constitutional law, Ireland and Korea would certainly not fall within the "most similar cases" logic (Hirschl 2005). Indeed, given all the variables involved, they might best be placed under Hirschl's "most different cases" logic. Ireland and Korea differ yet they do share a history of national division.

Past studies have tended to focus on Germany and Korea (M. Kang 1990; Gong 1993; Y. Park 1993; Yang 1999; Pfennig 2001; Seliger 2001; Kuechler 2002; Yang 2002; Kindermann 1998; Kindermann 2003). Germany and Korea also differ in many ways, but were both occupied and divided at the end of World War II. Occasionally, comparisons have been made to other countries like Vietnam, Yemen, Cyprus, and Mainland China/Taiwan (M. Lee 1994; S. Choi 2001; Geistlinger 2002; Wei 2003).

Koreans are sometimes described as being the Irish of the East when it comes to alleged cultural generalities (Myers 2001). Yet, a detailed comparative look at Ireland and Korea as divided nations seems to be lacking. In this article, I argue that the Northern Ireland Peace Process and the resulting agreement (Northern Ireland Act 1998), which goes by various popular names including 
the Good Friday Agreement, is an alternative legal and political model that can be adapted to reduce tensions on the Korean Peninsula. This would be consistent with the preference among many in South Korea for a gradual approach that has emerged especially in light of the various problems experienced by Germany stemming from reunification (Han 1998; Paik 1998; Moon and Roh 2002).

Admittedly, applying an Irish model to Korea would be something of a legal transplant. It would be a voluntary borrowing to be carefully adjusted (Berkowitz et al. 2003; Graziadei 2009). Using an approach similar to that of the Good Friday Agreement might even foster Korean reunification even though Ireland itself remains divided. In essence, the Irish model contains features that are arguably better suited to the Korean situation than the experience of either rapid yet costly German reunification (Flockton 2001) or politically unstable Yemeni reunification (Al-Suwaidi 1995; BBC News 2009).

\section{IRELAND AS A DIVIDED NATION}

\section{Historical background}

The entire island of Ireland had been under English control for centuries (Foster 1988). Pressure for Irish independence grew during the early years of the $20^{\text {th }}$ Century. This included a guerrilla war lead by the original, self-proclaimed Irish Republican Army (IRA). In 1920, the British government created the legal framework for separate parliaments in Dublin and Belfast (Government of Ireland Act 1920). Ireland was effectively partitioned even though the plan did not function quite as London had planned (Kee 1972). The partition created a northern entity with a Protestant/Ulster-Scots majority with the rest of the island being predominately Catholic/Irish. Later, an agreement was reached between London and representatives of Sinn Féin, the political party usually associated with the IRA. Under this agreement, known as the Anglo-Irish Treaty, Ireland achieved in 1922 a considerable measure of independence as a dominion called the Irish Free State (Irish Free State (Agreement) Act 1922). However, the North retained the right to opt out. Twenty-six counties stayed. The other six counties formed the new British province of Northern Ireland (The State (Gilsenan) v. McMorrow).

In 1937, the Irish Free State adopted a new constitution that loosened ties with London (Doolan 1999). Among other things, in this constitution the state was renamed as Ireland (Const. of Ireland, art. 4; Ellis v. O'Dea). Eventually, Ireland became a fully sovereign republic (Ireland Act 1949).

While the republic's recent history has been generally peaceful, Northern Ireland is a different story. The province witnessed decades of conflict most 
notably during a period commonly referred to as the Troubles (CAIN 2009). This period lasted roughly from the 1960 s through the late 1990s. It basically started with a civil rights movement. Activists sought an end to ethnic/religious discrimination. A backlash soon followed. In 1972, London suspended the provincial government and implemented direct rule (Northern Ireland (Temporary Provisions) Act 1972). The next year a referendum known as the Border Poll was held confirming that a majority of the voters in Northern Ireland wanted the province to remain a part of the United Kingdom (UK) (Northern Ireland (Border Poll) Act 1972). Elections were then held for a new Northern Ireland Assembly (Northern Ireland Assembly Act 1973; Northern Ireland Constitution Act 1973; Northern Ireland Constitution (Amendment) Act 1973). However, this system soon collapsed and direct rule from Westminster was introduced again (Northern Ireland (Emergency Provisions) Act 1973; Northern Ireland Act 1974).

Local rule was only reintroduced in 1982 (Northern Ireland Act 1982). Yet, in 1986, the Assembly was once again dissolved (A. Morgan 2000). Various proposals were made that ultimately resulted in the Good Friday Agreement, which will be discussed in more detail later. Since then, the province has become generally a more peaceful and stable place. Moreover, in the wake of the 9/11 attacks in the United States (US) certain groups wish to avoid being labeled as terrorists (Bew 2002).

The two communities are often described in stark bipolar terms (Rose 1976). They might be cast in sectarian terms, Protestant versus Roman Catholic, or else in broad political terms, Unionist versus Republican or Nationalist. The communities can also be described in ethnic terms, Ulster-Scots or Scots-Irish versus Irish. Furthermore, there is the matter of socio-economic class (Probert 1978).

The majority community is the Ulster-Scots. Many can trace their ancestry to Lower Scots who settled in Ireland during the $17^{\text {th }}$ Century as part of the Plantation of Ulster (Curtis 1937). Politically, the Ulster-Scots prefer the status quo of Northern Ireland remaining within the union (Rose 1976). Hence, they are often called Unionists. This is clearly reflected in the names of certain major political parties in the province like the Ulster Unionist Party (UUP) and the Democratic Unionist Party (DUP) (Goodman 2000).

The largest minority community in Northern Ireland is the Irish. The Irish can be viewed as being the native population at least in so far as their ancestors inhabited the entire island before the arrival of the Ulster-Scots (Kee 1972). Politically, they prefer change in the form of Northern Ireland someday reuniting with the rest of Ireland. Hence, they are usually called Republicans or Nationalists. Besides Sinn Féin, the other major Nationalist party is the Social Democratic and Labour Party (SDLP). Additionally, one finds certain smaller parties like the cross-community Alliance Party. 


\section{Previous peace efforts in Nortbern Ireland}

Prior to the Good Friday Agreement, there were other efforts to establish peace in Northern Ireland. The Sunningdale Agreement of 1973 saw the establishment of a pan-island Council of Ireland to deal with North/South issues (Sunningdale Agreement 1973; CAIN 2009). Also, within the province itself, the Sunningdale Agreement resulted in the creation of a power-sharing executive for Northern Ireland and the election of an assembly in the wake of direct rule from London that was imposed in 1972. The Sunningdale Agreement survived a constitutional challenged in the Irish courts (Boland v. An Taoiseach). However, the new provincial government failed due to strong resistance from certain Unionist groups.

The Anglo-Irish Agreement of 1985 was another past effort (Anglo-Irish Agreement 1985). The Anglo-Irish Agreement gave the republic a consultative role in the affairs of Northern Ireland (Hadfield 1986). This agreement also survived a challenge in the Irish courts (McGimpsey v. Ireland).

The more recent peace process can be traced to the Downing Street Declaration of 1993 , also known as the Joint Declaration, in which the British government stated that it had no selfish strategic or economic interest in Northern Ireland (Downing Street Declaration 1993). It also reaffirmed that Northern Ireland would remain a part of the UK until such time as a majority voted otherwise in a referendum. As a compromise, the declaration was criticized by some on both sides of the communal divide.

\section{The Good Friday Agreement}

On April 10, 1998, at the Multi-Party Talks on Northern Ireland, which were held at Stormont in Belfast, a relatively short yet complex and certainly significant agreement was reached between the then British Prime Minister Tony Blair, Irish Prime Minister Bertie Ahern, and leaders of several local political parties in Northern Ireland (O'Donnell 1999; McGarry 2001; A. Morgan 2000; Powell 2008). The talks had been facilitated by former US Senator George Mitchell, retired General John de Chastelain of Canada, and former Prime Minister Harri Holkeri of Finland. Among the various popular names, the Good Friday Agreement is perhaps the most widely used one today. April 10, 1998 happened to be Good Friday. However, Good Friday is followed by Easter, which has political overtones because of the Easter Rising of 1916, a major event in the Irish guerilla war. Alternatives include the Belfast Agreement and Stormont Agreement.

The Good Friday Agreement consists of several parts. It starts with a Declaration of Support. The tone of the Declaration of Support is suitably optimistic yet respectfully mindful of the history of violence in Northern Ireland. The Declaration of Support is followed by a section entitled Constitutional Issues. This section 
deals with the status of Northern Ireland and citizenship. Specifically, democratic choice is put forth as the basis for both the current status and future of Northern Ireland. It is recognized that the majority of the population of Northern Ireland presently wishes to remain within the UK and that any change in Northern Ireland's status would need to have the support of the majority of the population of the province. This assumes that people in the South would continue to support reunification.

Attached to the Constitutional Issues section are two Annexes containing draft British and Irish legislation. The draft British legislation in the first Annex was designed to repeal the Government of Ireland Act of 1920 and to enable the people of Northern Ireland to vote on the future of the province. The second Annex contains a proposed Amendment to the Irish Constitution whereby the text of Articles 2 and 3 of the Irish Constitution of 1937 would be dramatically reworded.

The rest of the Agreement features three Strands. Strand One entitled Democratic Institutions in Northern Ireland establishes the framework for a new provincial assembly and executive within the UK constitutional context of the devolution of powers from the central government to the provinces/countries that make up the UK (Brazier 1998). Nevertheless, devolution was suspended in Northern Ireland on a couple of occasions yet devolution has now been restored once more in Northern Ireland (Northern Ireland (St Andrews Agreement) Act 2006; Northern Ireland (St Andrews Agreement) Act 2007).

Strand Two establishes a North/South Ministerial Council (NSMC) to enable cooperation between the executive branches of Northern Ireland and the Republic of Ireland. The NSMC consists of a council of ministers from the each side. Strand Three establishes a new British-Irish Council (BIC) which deals with a range of East/West matters in summits normally attended by the heads of government from the UK and the Republic of Ireland as well as top local officials from Northern Ireland plus Scotland and Wales along with the Isle of Man, Guernsey, and Jersey. In addition, Strand Three establishes a British-Irish Intergovernmental Conference (BIIC or BIIGC).

Yet, the most important part of Strand Three is arguably the chapter on Rights, Safeguards and Equality of Opportunity that covers human rights and related issues. Specifically, the provisions on human rights in Strand 3 provide for the incorporation of the European Convention into the law of Northern Ireland. In fact, with the passing of the Human Rights Act of 1998 the entire UK was covered. Pursuant to Strand 3, a new Human Rights Commission was set up for Northern Ireland with representation from both major communities (Harvey 2006). Meanwhile, as agreed, the republic has set up a similar body for the rest of the island. Likewise, the republic has incorporated the European Convention into Irish law (European Convention on Human Rights Act 2003). In Strand 3, the Irish government also agreed to ratify the Council of Europe 
Framework Convention for the Protection of National Minorities (Framework Convention for the Protection of National Minorities 1995).

By far, the most complicated provisions of Strand Three to implement in practice have been those on the decommissioning of weapons held by various paramilitaries in Northern Ireland. Some splinter groups came out against the Northern Ireland Peace Process (CAIN 2009).

\section{Constitutional change in the republic}

Ireland has a written constitution with provisions for the separation of powers (D. Morgan 1997). The present constitution dates from 1937 (Const. of Ireland; Finlay 1998). Constitutional change in Ireland cannot be done merely by legislation. The amending method is that of a constitutional referendum (Const. of Ireland, arts. $46 \& 47)$. A referendum bill must pass both houses of the Irish Parliament. A referendum is then held. To incorporate the Good Friday Agreement, such a referendum was held in the Republic of Ireland in 1998. The referendum was one of the early successes of the peace process. It indicated widespread support in the republic for the Good Friday Agreement.

The proposed new Article 2 dropped Dublin's territorial claim on Northern Ireland while the new Article 3 dropped Dublin's somewhat vague provision on the application of Irish law (O'Donnell 1999). These were upheld in Riordan v. An Taoiseach (No. 2).

Previously, the Constitution of Ireland in Article 2 made a broad territorial claim:

The national territory consists of the whole island of Ireland, its islands and the territorial seas.

Hence, this claim by implication included the entire province of Northern Ireland as being de jure part of Ireland. This implied that de facto British rule in Northern Ireland was illegitimate. Yet, Dublin always maintained diplomatic relations with London. Moreover, Ireland and the UK jointly entered the European Economic Community (EEC), which later became the European Union (EU).

A related provision of the Irish Constitution, Article 3, ran as follows:

Pending the re-integration of the national territory, and without prejudice to the right of the Parliament and Government established by this Constitution to exercise jurisdiction over the whole of that territory, the laws enacted by that Parliament shall have the like area and extent of application as the laws of Ireland and the extra-territorial effect. 
While not exactly a model of clarity in constitutional drafting, this provision was effectively a limitation on the application of Irish law to the territory under the actual control of Dublin (McGimpsey v. Ireland).

The new wording of Article 2 is as follows:

It is the entitlement and birthright of every person born in the island of Ireland, which includes its islands and sea, to be part of the Irish nation. That it is also the entitlement of all persons otherwise qualified in accordance with law to be citizens of Ireland. Furthermore, the Irish nation cherishes its special affinity with people of Irish ancestry living abroad who share its cultural identity and heritage.

Article 2 thus drops the territorial claim. At the same time, it articulates an inclusive vision of Irish citizenship that reaches out to people from both traditions in Northern Ireland as well as to people of Irish extraction overseas (Clarke 2000).

Article 3 was dramatically altered as well. Indeed, it was entirely rewritten and divided into two sections as follows:

Article 3.1. It is the firm will of the Irish nation, in harmony and friendship, to unite all the people who share the territory of the island of Ireland, in all the diversity of their identities and traditions, recognising that a united Ireland shall be bought about only by peaceful means with the consent of a majority of the people, democratically expressed, in both jurisdictions in the island. Until then, the laws enacted by the Parliament established by this Constitution shall have the like area and extent of application as the laws enacted by the Parliament that existed immediately before the coming into operation of this Constitution.

Article 3.2. Institutions with executive powers and functions that are shared between those jurisdictions may be established by their respective responsible authorities for stated purposes and may exercise powers and functions in respect of all or any part of the island.

At the same time, two new provisions, Articles $29.7 \& 29.8$, were added. They have received less scrutiny. Article 29.7 has two parts. Article 29.7 (1) expressly incorporates the Good Friday Agreement into Irish law. Article 29.7(2) paves the way for intergovernmental cooperation envisioned under the Agreement: 
Article 29.7(1). The State may consent to be bound by the British-Irish Agreement done at Belfast on the 10th day of April, 1998, hereinafter called the Agreement.

Article 29.7(2). Any institution established by or under the Agreement may exercise the powers and functions thereby conferred on it in respect of all or any part of the island of Ireland notwithstanding any other provision of this Constitution conferring a like power or function on any person or any organ of State appointed under or created or established by or under this Constitution. Any power or function conferred on such an institution in relation to the settlement or resolution of disputes or controversies may be in addition to or in substitution for any like power or function conferred by this Constitution on any such person or organ of State as aforesaid.

Article 29.8 clarifies the application of Irish law outside of Ireland. It rejects any special application of Irish law in Northern Ireland:

Article 29.8. The State may exercise extra-territorial jurisdiction in accordance with the generally recognized principles of international law.

Collectively, the new provisions clearly demonstrate a profound change in vision in the interest of peace on the island. Instead of being overly concerned with formalistic models of federation, confederation, or commonwealth, the Good Friday Agreement and the relevant amendments to the Irish Constitution focus on democracy, tolerance, and pragmatism (Fearon and McWilliams 1999). Here it is worth noting that the respective institutional roles played by the NSMC, $\mathrm{BIC}$, and BIIGC have all helped to build confidence in the peace process as a whole.

However, there have been problems with the full implementation of the Good Friday Agreement. It has proven difficult to make power sharing work. The provincial government was suspended in 2000 (Northern Ireland Act 2000) and then again in 2002. Fresh assembly elections were held in 2003 (Northern Ireland Assembly Elections Act 2003; Northern Ireland Assembly (Elections and Periods of Suspension) Act 2003; Northern Ireland (Monitoring Commission etc.) Act 2003) and once again in 2007. Likewise, taking the gun out of politics took longer than expected (Northern Ireland Arms Decommissioning Act 1997; Northern Ireland Arms Decommissioning (Amendment) Act 2002). Yet, considerable progress has been made (Independent International Commission on Decommissioning 2005; Independent International Commission on Decommissioning 2009). 


\section{SYMBOLIC POWER}

A constitution typically provides the framework for a jurisdiction's legal system. Yet, as important as that role is, there are more to constitutions than just providing legal frameworks. Constitutions also possess symbolic power (Nichol 2003). The German philosopher Jürgen Habermas has described how national consciousness developed in Europe especially during the $19^{\text {th }}$ Century (Habermas 1998b). According to Habermas, people began to remodel their loyalties beyond family, village, region, dynastic ruler, and clerical authority. The nation-state became the new focus. This nation was in a sense artificial because it was imagined as a natural community of language and descent with a constructed historical destiny. Constitutionally based nationhood leads to the realization of what Habermas calls a civic conception of a nation versus a merely ethnic one (Habermas 1998c; Habermas 2006b).

\section{SYMBOL OF NATIONHOOD}

In the past, states were often equated majority cultures. A contiguous territory was an important factor (Connolly 1993). But, today most nation-states are actually heterogeneous (Schnapper 1994). A country's constitution can serve as an important symbol of nationhood. This civic identity can potentially transcend various differences.

\section{CONSTITUTIONAL PATRIOTISM}

The German political scientist Dolf Sternberger is credited with coining the term Verfassungspatriotismus or "constitutional patriotism" (Welsh et al. 1997; Müller 2006). The term was then adopted by Habermas (Habermas 1996; Habermas 2001). In his take on constitutional patriotism, Habermas, considers the impact of the French Revolution on the rise of the modern state (Habermas 1994; Habermas 1996). France became a model. The nation-state would replace small fiefdoms, city-states, and multinational empires albeit sometimes at the expense of minority groups. However, some states like the US and the former Soviet Union did not neatly fit into the model because they were multiethnic societies to a greater extent than most countries in Europe.

In Habermasian constitutional patriotism, a shared political identity is inspired by a constitution that effectively protects human rights and transcends differences in ethnicity, language, culture, and religion. Constitutional patriotism, as a new political culture, moves beyond traditional, often majority ethnic group-based, nationalism towards civic nationalism and even cosmopolitanism. Of course, con- 
stitutional patriotism does have some critics (Abraham 2007; Müller 2007). However, Habermas acknowledges that national traditions are important. Universal ideals of democracy and human rights are interpreted in the context of a particular nation's history and culture.

Habermas uses both Switzerland and the US (Habermas 1994; Habermas 1996) as examples of multicultural countries where forms of constitutional patriotism have already been realized (Habermas 1996; Michelman 1999). To Habermas, these countries show that: "a political culture in which constitutional principles can take root need by no means depend on all citizens' sharing the same language or the same ethnic and cultural origins." (Habermas 1996, 499). Moreover, "[a] liberal political culture is only the common denominator for a constitutional patriotism (Verfassungspatriotismus) that heightens an awareness of both the diversity and the integrity of the different forms of life coexisting in a multicultural society." (Habermas 1996, 500) (emphasis in the original).

Habermas also argues for a pan-European constitution (Habermas 2006a; Habermas 2006b). He maintains that a type of pan-European constitutional patriotism should be developed for the EU as a whole (Habermas 2001). He distinguishes between three camps namely, the Euro-skeptics, Neo-conservatives, and Euro-federalists. Euro-skeptics are those who are highly critical of the vision of the EU preferring national sovereignty. For example, Euro-skeptics opposed the creation of the euro as a common currency. Neo-conservatives, or market liberals, view the EU primarily as a common market and hence a means towards regional economic integration, enhancing competition, and even further privatization. However, Euro-federalists seek to deepen political ties and to address the alleged democracy deficit in the EU by strengthening the role of the European Parliament and so on. Habermas himself takes an essentially Euro-federalist position. As this is being written, the EU is in the process of getting a constitution of a sort in the form of the Lisbon Treaty (Europa 2009).

But, how might constitutional patriotism impact divided nations? Habermas admits that a sense of shared cultural identity is clearly important in the case of divided nations (Habermas 1998a). Yet, the German experience has shown that even after reunification significant differences can remain. Constitutional patriotism has the potential to foster a new national identity. Besides mere ethnic bonds, the people in a reunified nation can share in a political culture based on democracy, the rule of law, and human rights.

A form of island-wide constitutional patriotism could greatly benefit Ireland and help to heal the wounds of past conflicts. It would give all the peoples of the island a new identity. Already some efforts have been made in this direction. For example, the new Articles 2 and 3 of the Irish Constitution employ inclusive language to reach out to Ulster-Scots community in Northern Ireland. Furthermore, if the Habermasian vision of pan-European constitutional patriotism could be realized, then that would also benefit the peoples of the island. 
Unlike so much of the world today, the two Koreas are essentially homogenous states. Yet, Koreans have been divided politically, economically, and socially in terms of North and South. Hence, a reunified Korea would face many challenges (Y. Lee 2002).

Here the German experience is informative. Many in the former German Democratic Republic (GDR) identified more with being German than with being specifically East German (Childs 2001). This was so despite the official GDR position that it was a distinct nation due to its Socialist system (GDR Const. of 1968, art. 1 \& GDR Const. of 1974, art. 1; cf. GDR Const. of 1949, art. 1). Yet, in the years since reunification, some speak of Die Mauer im Kopf, literally "The wall in the head." This expression refers to the lingering psychological and cultural divide between Germans from East and West (Abshire 2004). In light of the German experience, a form of Korean constitutional patriotism should be developed to move beyond traditional Korean nationalism.

\section{REUNIFICATION AS A GOAL}

During the past two decades the world has witnessed some opposing trends. Regional integration and globalization have brought countries increasingly together yet at the same time secessionist movements abound (Waters 2006). However, divided nations can be considered as a special category.

The South Korean Constitution speaks of the mission of peaceful unification of the homeland in its Preamble as well in both Articles 4 and 69 (ROK Const., preamble, art. 4, art. 69). The Preamble of the North Korean Constitution refers to Korean reunification as well in the context of praising the late Kim Il Sung, who was the father of the current ruler Kim Jong Il, and promoting the ideology of Juche or self-reliance (Yoon 2004).

\section{VARYING CONSTITUTIONAL APPROACHES TO REUNIFICATION}

Certainly, there are different approaches towards seeking reunification as well as different visions of what a reunited country might look like. Some constitutions might declare unification as a goal yet can be vague by the means of achieving the goal. They do not set out a detailed plan for reunification. Such plans are perhaps more in the realm of diplomacy. This is certainly true of both the North and South Korean constitutions.

However, sometimes a constitution might contain one or more provisions that provide a specific basis for reunification. For instance, the former West German Basic Law contained two different provisions, Article 23 and Article 146, which 
could have legally supported complete reunification with East Germany (Pile 2001). Under the old Article 146, German reunification could have been achieved by means of drafting a new constitution for all of Germany. This approach had been favored by many on the political Left in West Germany especially the then opposition Social Democrats.

By contrast, under the old Article 23, German reunification could have been achieved by simply expanding the territory of the Federal Republic of Germany (FRG) with the admission of the new states (Länder) in the East. So, instead of East Germany entering as a whole entity, five new states along with East Berlin joined the FRG.

This fast-track method was favored by West Germany's then conservative government under Chancellor Kohl. Ultimately, it was the method actually employed along with a set of two inter-German treaties (Monetary, Economic and Social Union Treaty 1990; Unification Treaty 1990) and the treaty restoring full sovereignty to Germany from the lingering sovereignty exercised by the Four Powers (US, Soviet Union, UK, and France) that had occupied Germany at the end of World War II (Treaty on Final Settlement with respect to Germany 1990). Nevertheless, rapid reunification has come at a cost. Higher taxes and higher unemployment especially in the East can be traced to German reunification nearly two decades later. Social divisions persist as was mentioned earlier.

My article examines the relevance of the Northern Ireland Peace Process to the problem of Korean reunification. My basic argument is that the Good Friday Agreement that came out of the Northern Ireland Peace Process can serve as a model for Koreans to adapt to their needs for easing tensions, improving ties, and, ultimately, realizing reunification of the peninsula. Ireland, even though the island remains divided and also despite the fact that reunification is not a necessary outcome of the peace process in Northern Ireland, offers hope for Koreans. As such, Ireland is potentially a better model than Germany.

\section{HARNESSING CONSTITUTIONAL POWER FOR KOREA}

Habermasian constitutional patriotism need not be limited to Germany or even Europe. It could be developed in Korea and utilized for the cause of Inter-Korean reconciliation and possible Korean reunification. The two Korean constitutions already have symbolic power for their respective countries. Both constitutions could be creatively used to facilitate a series of political negotiations, confidence-building measures, public participation, implementation, and eventually the goal of reunification roughly along lines of the inclusive approach to easing tensions and power-sharing found in the Northern Ireland Peace Process. However, in order to do so, certain amendments should be made.

Amending the South Korean Constitution to ease tensions could start with 
the territorial claim. Article 3 claims the entire Korean Peninsula and its offshore islands for South Korea (ROK Const., art. 3). This implies that North Korea is not a legitimate entity. Ireland had a similar claim on Northern Ireland, but it has since drop its claim. Article 3 is not the only thing that should be changed, but it is a good place to start. Dropping the territorial claim should help to reduce tensions with the North and encourage greater inter-Korean cooperation in various fields. Changes need to be made to the North Korean Constitution as well. Article 1 of the North Korean Constitution claims that North Korea represents the interests of all Koreans. This implies that South Korea is not a legitimate entity although the provision is not a territorial claim per se.

In the long run, there could be a new pan-Korean Constitution for a reunified state. While the possibility of the sudden absorption of North Korea under the current South Korean Constitution or South Korea under the North Korean Constitution cannot be completely ruled out, this seems unlikely and could be undesirable.

While it is anyone's guess what a future pan-Korean Constitution would actually look like, we can at least envision the process that might be used. Ideally, the text would be negotiated by both sides. The proposed text could then be voted upon either by both governments or directly by the Korean people. Indeed, reunification is one of the policy areas for potential referenda specifically mentioned in Article 72 of South Korea's constitution (ROK Const., art. 72). This approach assumes that the political actors perceive that there is enough time for such a process.

\section{APPLYING THE IRISH EXPERIENCE TO THE TWO KOREAS}

\section{Appeal of the model}

Reflecting on the partition of Ireland along with the Northern Ireland Peace Process that resulted in the Good Friday Agreement of 1998 offers a fresh way of looking at the constitutional aspects of the Korean Problem and indeed the plight of divided nations generally. The key to the peace process has been a creative compromise. The essence of the Irish experience has been a vision based on the principles of tolerance, cooperation, peace, and democracy. It is a pragmatic vision that goes beyond approaches used in the past for similar conflicts that typically involved proposing a federal solution or some form of confederation (Koh 2002). Instead, the Irish model is one of power-sharing within the province along with support from the governments in London and Dublin. Like any model, the Irish model would have to be carefully adjusted to the distinctive aspects of the Korean situation. 


\section{The model itself}

The Irish model, which was introduced earlier, can be divided into at least four different stages. The first stage of the model would be that of political negotiations. A series of political negotiations lasting about two years preceded the Good Friday Agreement (Wilford 2001). Some were carried out with public knowledge while others were carried out in secret involving backchannels (Anderson 2002; Powell 2008). Initially, they involved negotiations among parties within the same community as well as negotiations across the communal divide and also between the British government and various players (Bew 2002). Eventually, the major groups involved in the conflict were represented at the talks in Belfast that led to the Good Friday Agreement. Ensuring a high degree of inclusiveness in the talks was a key element in reaching an agreement that could enjoy broad support within Northern Ireland as well as in the rest of the UK and in the republic.

Once a political agreement was reached it was time for the second stage, which involved various confidence building measures. This involved matters like the release of people who were viewed by one side or another of the communal divide as being political prisoners, i.e., members of the various paramilitaries that were serving prison sentences (Northern Ireland (Sentences) Act 1998), the commitment towards setting up human rights commissions for Northern Ireland and Ireland (Harvey 2006), and the proposal for amending the Irish Constitution.

The third stage involved the referenda on the Good Friday Agreement in both parts of the island with the referendum held in the republic also including the proposed amendments to the Irish Constitution (Bew 2002). This stage got the voters directly involved in both parts of the island. Moreover, in the republic, the public could focus on the constitution and the power of the constitution.

The fourth stage has been the follow-up. Governmental power was devolved to Northern Ireland and new cross-border institutions were established (Hadfield 2001). A new police force, the Police Service of Northern Ireland, was created to replace one, the Royal Ulster Constabulary, which had been mistrusted for alleged bias by many members of the minority in the province (Police (Northern Ireland) Act 2000).

\section{THE IRISH MODEL FOR KOREA}

The Irish model, especially the process used in Northern Ireland, is relevant for conflicts in other parts of the world. It can be tailored to a variety of situations.

For the first stage, the key difference in Korea is that the negotiations are 
essentially between just two governments. The process could, in theory at least, be easier than the negotiations that preceded the Good Friday Agreement because there are fewer political players in the overt sense. Outside powers would have an interest in such developments (W. Lim 2009). But, unlike either the case with the Six-Party Talks on North Korea's nuclear program that have involved the two Koreas along with China, Japan, Russia, and the US (E. Lee 2004; Yang 2007; Paige 2008) or the Two plus Four Talks surrounding German reunification that involved the two Germanys along with the US, Soviet Union, UK, and France, outside powers would not need to be formally incorporated except for the matter of a final peace treaty formally ending the Korean War because China and the US were major combatants.

Indeed, both the DPRK and the ROK wish for the Korean Problem to be dealt with solely by the two Koreas. This stance goes back at least as far as 1972 when a series of talks were held between representatives of the two Koreas (South-North Joint Communiqué 1972). It was reaffirmed during the first ever inter-Korean summit (South-North Joint Declaration 2000). A shared sense of Korean nationalism is presumably at least partly behind this sentiment. Nevertheless, mediation can prove useful when negotiations stall.

So far there have been some negotiations between the two Koreas that resulted in the June 2000 Summit followed in December 2000 by a set of agreements on Inter-Korean economic cooperation (Jhe 2004). Another summit was held in 2007.

A dedicated complex for South Korean tourists has been set up in the Diamond Mountains (Mt. Kumgang or Geumgang-san) of North Korea (Noland 2000; Jaung 2002; Mason 2009). Likewise, an industrial zone for South Korean companies was set up in the North Korean border town of Kaesong (also transliterated as Gaesong) with certain parts of Kaesong being opened up to visits by South Korean tour groups (E. Lim 2007). Both projects are managed by Hyundai Asan (Hyundai Asan 2009). These projects have arguably proven to be more successful than other North Korean attempts at economic reform (Goedde 2004). A limited level of economic cooperation appears to be generally acceptable to the authorities in both Koreas not only because it produces mutual benefits, but also because it does not pose any immediate threats to the political systems of either side. However, such projects are not without their critics (Wijekoon 2008).

For the second stage, confidence building measures are needed. Releasing any remaining political prisoners and detainees would be helpful to the process. Increased family reunions for members of divided families would also be advisable. Besides the obvious humanitarian aspect, having such regular person-to-person contacts can help develop interactions between ordinary Koreans. Reducing the level of the forces deployed along either side of the Demilitarized Zone (DMZ) would also be a major confidence-building measure. Another issue is the future 
of American military bases (Dujarric 2000).

Specifically, legal changes could involve a proposal to amend Article 3 of the South Korean Constitution to drop the territorial claim on the North along with moves to amend or abolish the National Security Law. For its part, North Korea could also propose changes to its constitution like removing the claim to represent the interests of all Koreans found in Article 1 of the North Korean Constitution. Ideally, the North Korean government could improve the human rights situation within North Korea, which is generally regarded as being quite poor.

The third stage would entail amending the ROK Constitution pursuant to Article 130. This involves a supermajority in the National Assembly and then a referendum. Such a procedure would focus the public on improving ties with the North with what might be a lively debate within the parliament and in society at large. Such process would be a historic step because until now the people of South Korea have not had any direct say in efforts at reconciliation with North Korea. A constitutional referendum on this issue, if passed, would give some real sense of degree of public support for better relations with the North. A mandate would be desirable in view of the challenges involved.

Meanwhile, any changes to the North Korean Constitution could simply be made by Supreme People's Assembly pursuant to Article 91 of the DPRK Constitution. Under current political conditions in the North, the Supreme People's Assembly is almost certain to approve anything that the top leadership proposes.

These constitutional changes would be particularly important because of their symbolic power and because they lay the groundwork for a kind of constitutional patriotism. Truly ending the lingering Cold War structure on the Korean peninsula could be realized in part by means of such constitutional changes. Habermasian constitutional patriotism can play a role in fostering Inter-Korean reconciliation. Furthermore, constitutional patriotism can ultimately support Korean reunification.

The fourth and final stage would be that of follow-up. This might prove to be the most difficult stage. Certainly, the follow-up stage has been difficult in the Northern Ireland Peace Process. Moreover, if we look at inter-Korean relations, there has been a series of setbacks since the 2000 Summit despite the holding of a second summit in 2007.

\section{RELEVANCE OF THE MODEL}

The Northern Ireland Peace Process involved at least four different stages. A similar process with political negotiations, confidence building measures, voter involvement, and follow-up could be used in reducing tensions and promoting peace on the Korean Peninsula. The Irish model is not a model of reunification 
per se because Irish reunification is not guaranteed. Rather, it is a way of promoting peace.

On the issue of territory, the Irish Constitution previously made a claim on Northern Ireland. The lack of a constitutional territorial claim by West Germany did not hinder speedy German reunification. Likewise, the dropping of the territorial claim to Northern Ireland as part of the Northern Ireland Peace Process need not hinder reunification of the island someday. Furthermore, the amended Irish Constitution might serve as the basis for a fresh Irish civic national identity and pan-Irish constitutional patriotism. The amended version of the Irish Constitution represents a possible model for South Korea. Following the Irish model could improve inter-Korean ties and thereby ease tensions in Northeast Asia without giving up on the goal of eventual reunification. Also, it does not mean ignoring the rights of North Koreans who wish to settle in South Korea.

Besides the territorial issue, the Irish model is relevant for its overall pragmatic approach to intergovernmental cooperation. The two Koreas could follow the Irish model in coordinating public policy in various areas like fisheries and tourism. Already some rail and road links between the two Koreas have been restored. There have also been efforts at protecting investments by South Korean businesses in North Korea and providing for commercial arbitration to resolve business disputes (K. Kim 2003).

Other parts of the Irish model are also instructive. Releasing any remaining political prisoners, for example, would be an important confidence-building measure. In the context of the Korean peninsula, this should be expanded to include any other detainees or abductees that might still be held.

Enhancing human rights is another important aspect. In both Northern Ireland and the republic, Human Rights Commissions were set up and new human rights laws were passed. This created a new legal framework island-wide. This sort of initiative might prove much more difficult in the Korean context, but it would be an important step.

As important as all of these aspects of the Irish model are, we should not lose sight of the significant symbolic role that constitutions can play in the process of reunification. Constitutions can provide a legal framework for historic change. On another level, constitutions can also serve as symbols of nationhood and foster a sense of Habermasian constitutional patriotism. Ultimately, this can help to develop a new national identity.

\section{TOWARDS REUNIFICATION?}

Reunification is not the stated objective of the Irish peace process although some people in Northern Ireland and beyond do see it as way to facilitate eventual Irish reunification. However, for some participants in the process re- 
unification remains very much something to be avoided. For others still the peace process might actually be seen as being an obstacle to reunification. Regardless of the various perspectives, the fact is that Northern Ireland remains in union with the rest of UK even under devolution.

A key to the Northern Ireland Peace Process has been the recognition that certain basic conditions would have to be met for reunification. Specifically, Ireland would be reunified only peacefully and only with the democratic consent of the majorities in both parts of Ireland. Although the current political situation on the Korean Peninsula is very different from that on the island of Ireland, one could reasonably maintain that Korea too should only be reunified peacefully rather than through military force as had happened in Vietnam. Moreover, ideally the majority of the population in each of the two Koreas should indicate unequivocal support for reunification. This could be done by means of referenda. Holding either a referendum or multiparty elections in North Korea would obviously require historic change. At present, of course, there is no provision for either referenda or multi-party elections in North Korea's constitution. Indeed, the constitution guarantees the leadership of the Workers' Party of Korea (DPRK Const., art. 11). This scenario further assumes that North Korea does not suddenly collapse.

Reuniting Korea would likely be even more difficult than German reunification has proven to be in light of the vast differences in the legal, political, economic, and educational systems of the two Koreas (Goedde 2004; C. Choi 2005). Another factor is the relative size of North Korea vis-à-vis South Korea, which would make it more difficult for South Korea to absorb North Korea than it was for West Germany to absorb East Germany. Greater inter-Korean cooperation could thus help to improve the level of economic development in the North while also benefiting the South and potentially setting the stage for reunification.

Socially, North Koreans and South Koreans have had only extremely limited interaction with one another for more than half a century. An indication of some of the challenges that would face a reunified Korea can be gleaned from the practical difficulties experienced by North Koreans who have defected to South Korea in adjusting to life in a Capitalist society (Grinker 1998; Kim and Lee 2003).

For years, some commentators have been predicting a sudden collapse of the North Korean state (Dujarric 2000). So far, however, North Korea has defied such expectations. North Korean famines may have killed a large yet undetermined number of individuals and encouraged others to flee the country, yet the regime remains in place (K. Lee 2008). China's economic reforms have apparently been studied by the leadership in Pyongyang, but so far there has only been some tinkering with the North Korean economic system (Goedde 2003; E. Lee 2004). Any dramatic change involving a major opening to the outside world could call into question the very existence of North Korea as a state. Hence, under 
present conditions at least, the regime in Pyongyang appears to have little incentive to enact major economic let alone political reforms (G. Kang 2006).

There is still some possibility of regime change brought about by American military action (Kim and Howe 2004). However, the price in blood and dollars could be very high. If nothing else, the official DPRK position has long been a defiant one (Li 1993).

\section{BEYOND REUNIFICATION}

Assuming that Korea is reunified someday, a new national identity will be needed. In this age of globalization, a cosmopolitan (or even post-national) form of civic nationalism is more fitting than old fashioned ethno-nationalism. A Habermasian constitutional patriotism, which comes from and supports a charter that guarantees democracy and protects human rights, is the key. A type of pan-Korean constitutional patriotism could be the basis for a new reunited Korean identity. In the future, Koreans, with the experience of reunification behind them, might also play a major role in someday forging a truly pan-Asian identity (Acharya 2008). Perhaps such a pan-Asian identity would even be along the lines of the pan-European identity that Habermas seeks in his vision of the future role of the EU.

\section{REFERENCES}

\section{Constitutions}

Basic Law (1949 \& as amended) [West Germany \& Reunified Germany] Const. of Ireland

DPRK Const. (1998) [North Korea]

GDR Const. (1949, 1968, and 1974) [East Germany]

ROK Const. (as amended in 1987) [South Korea]

\section{Statutes and international agreements}

Anglo-Irish Agreement 1985

Declaration on the Advancement of South-North Korean Relations, Peace and Prosperity 2007 [North \& South Korea]

Downing Street Declaration 1993

European Convention on Human Rights Act 2003 [Ireland]

Framework Convention for the Protection of National Minorities 1995

Government of Ireland Act 1920 
Human Rights Act 1998 [UK]

Ireland Act 1949

Irish Free State (Agreement) Act 1922 [Anglo-Irish Treaty]

Monetary, Economic, and Social Union Treaty 1990 [East \& West Germany]

National Security Law [South Korea]

Northern Ireland Act 1974

Northern Ireland Act 1982

Northern Ireland Act 1998 [Good Friday Agreement]

Northern Ireland Act 2000

Northern Ireland Arms Decommissioning Act 1997

Northern Ireland Arms Decommissioning (Amendment) Act 2002

Northern Ireland Assembly Act 1973

Northern Ireland Assembly Elections Act 2003

Northern Ireland Assembly (Elections and Periods of Suspension) Act 2003

Northern Ireland (Border Poll) Act 1972

Northern Ireland Constitution Act 1973

Northern Ireland Constitution (Amendment) Act 1973

Northern Ireland (Emergency Provisions) Act 1973

Northern Ireland (Monitoring Commission, etc.) Act 2003

Northern Ireland (Sentences) Act 1998

Northern Ireland (St Andrews Agreement) Act 2006

Northern Ireland (St Andrews Agreement) Act 2007

Northern Ireland (Temporary Provisions) Act 1972

Police (Northern Ireland) Act 2000

South-North Joint Communiqué 1972 [North \& South Korea]

South-North Joint Declaration 2000 [North \& South Korea]

Sunningdale Agreement 1973

Treaty on Final Settlement with respect to Germany 1990 [East Germany, West Germany, France, the United Kingdom, United States, and Soviet Union]. Unification Treaty 1990 [East \& West Germany]

\section{Cases}

Boland v. An Taoiseach, [1974] I.R. 338.

Ellis v. O'Dea, [1989] I.R. 530.

McGimpsey v. Ireland, [1990] 1 I.R. 110.

Riordan v. An Taoiseach (No. 2), [1999] 4. I.R. 343

The State (Gilsenan) v. McMorrow, [1978] I.R. 360 


\section{Other sources}

Abraham, David. 2007. Constitutional Patriotism, Citizenship, and Belonging in America and Germany. Temple Political E Civil Rights Review 16(2): 457-472. Abshire, Jean E. 2005. Interpretive Essay in Events that Changed Germany, ed. Frank W. Thackeray. Westport, CT: Greenwood Press.

Acharya, Amitav. 2008. The Imagined Community of East Asia in Northeast Asia and the Two Koreas: Metastability, Security, and Community, eds. Hyung-Kook Kim et al. Seoul: Yonsei University Press.

Al-Suwaidi, Jamal S. 1995. Introduction in The Yemeni War of 1994: Causes and Consequences, ed. Jamal S. Al-Suwaidi. Abu Dhabi: The Emirates Center for Strategic Studies and Research.

Anderson, Mark. 2002. Endgame in Ireland (video). Alexandria, VA: PBS Home Video.

BBC News. 2009. Country profile: Yemen. http://news.bbc.co.uk.

Berkowitz, Daniel, Katharina Pistor, and Jean-Francois Richard. 2003. The Transplant Effect. American Journal of Comparative Law 51: 163-203

Bew, Paul, Peter Gibbon, and Henry Patterson. 2002. Northern Ireland 1921-2001: Political Forces and Social Classes, Rev. edition. London: Interlink Publishing Group.

CAIN. 2009. University of Ulster, CAIN Web Service, Conflict Archive on the Internet. http://cain.ulst.ac.uk/index.html

Childs, David. 2001. The Fall of the GDR: Germany's Road to Unity. London: Longman.

Choi, Chongko. 2005. Law and Justice in Korea: South and North. Seoul: Seoul National University Press.

Choi, Sukyong. 2001. Divided States in Preventive Negotiation: Avoiding Conflict Escalation, ed. I. William Zartman. Lanham, MD: Rowman \& Littlefield Publishers, Inc. http://www.wilsoncenter.org

Clarke, Desmond M. 2000. Nationalism, the Irish Constitution, and Multicultural Citizenship. Northern Ireland Legal Quarterly 51(1): 100-119.

Connolly, William E. 1993. Democracy and Territoriality in Reimagining the Nation, eds. Marjorie Ringrose and Adam J. Lerner. Buckingham: Open University Press.

Curtis, Edmund. 1937. A History of Ireland, $3^{\text {rd }}$ ed. London: Methuen \& Co. Doolan, Brian. 1999. Principles of Irish Law, $5^{\text {th }}$ ed. Dublin: Gill \& Macmillan. Dujarric, Robert. 2000. Korean Unification and After: The Challenge for U.S. Strategy. Indianapolis, IN: Hudson Institute.

Europa. 2009. Treaty of Lisbon: Taking Europe into the $21^{\text {st }}$ Century. http://europa.eu

Fearon, Kate and Monica McWilliams. 1999. The Good Friday Agreement: A Triumph of Substance over Style. Fordham International Law Journal 22(4): 
1250-1272.

Finlay, Thomas A. 1998. The Constitution Fifty Years On. Dublin: Round Hall. Flockton, Christopher. 2001. The German Economy since 1989/90: Problems and Prospects in Germany since Unification: The Development of the Berlin Republic, $2^{\text {nd }}$ edition, ed. Klaus Larres. Houndmills, England: Palgrave.

Foster, R.F. 1988. Modern Ireland, 1600-1972. London: Allen Lane.

Geistlinger, Michael. 2002. Nation-Building for Korean Unification in Constitutional Handbook on Korean Unification. Volume III: Law Issues, eds. Sung-Hee Jwa et al. Seoul: Korea Economic Research Institute.

Goedde, Patricia. 2003. The Basic Law of the Sinuiju Special Administrative Region: A Happy Medium between the DPRK Constitution and Hong Kong Basic Law? Journal of Korean Law 3(2): 77-138.

2004. The Evolution and Challenges of the North Korean Legal System.

Fordham International Law Journal 27(4): 1265-1288.

Goodman, James. 2000. Single Europe, Single Ireland?: Uneven Development in Process. Dublin: Irish Academic Press.

Gong, Gerrit. W. 1993. Korean Unification: Implications for the United States and Northeast Asia in Korean Unification: Implications for Northeast Asia. Honolulu, HI: Pacific Forum/Centre for Strategic and International Studies.

Graziadei, Michele. 2009. Legal Transplants and the Frontiers of Legal Knowledge. Theoretical Inquiries in Law 10(2): 723-743.

Grinker, Roy Richard. 1998. Korea and Its Futures: Unification and the Unfinished War. New York: St. Martin's Press.

Habermas, Jürgen. 1994. Citizenship and National Identity in The Condition of Citizenship, ed. Bart van Steenbergen. London: Sage Publications.

. 1996. Between Facts and Norms: Contributions to a Discourse Theory of Law and Democracy, trans. William Rehg. Cambridge, MA: MIT Press.

. 1998a. National Unification and Popular Sovereignty in Habermas and the Korean Debate, ed. Sang-Jin Han. Seoul: Seoul National University Press. . 1998b. The European Nation State in Sovereignty in Habermas and the Korean Debate, ed. Sang-Jin Han. Seoul: Seoul National University Press. . 1998c. Civil Society and the Constitutional State in Habermas and the Korean Debate, ed. Sang-Jin Han. Seoul: Seoul National University Press. . 2001. The Postnational Constellation: Political Essays, trans. Max Pensky. Cambridge, MA: MIT Press.

. 2006a. The Divided West, ed. \& trans. Ciaran Cronin. Cambridge, England: Polity Press.

. 2006b. Time of Transitions, eds. \& trans. Ciaran Cronin and Max Pensky. Cambridge, England: Polity Press.

Hadfield, Brigid. 1986. The Anglo-Irish Agreement 1985-Blue Print or Green Print? Northern Ireland Legal Quarterly 37(1): 1-28.

. 2001. Seeing it Through? The Multifaceted Implementation of the Belfast 
Agreement in Aspects of the Belfast Agreement, ed. Rick Wilford. Oxford: Oxford University Press.

Han, Sang-Jin. 1998. Four Critical Issues of the Korean Unification: An Extrapolation of Habermas' Lecture in Habermas and the Korean Debate, ed. Sang-Jin Han. Seoul: Seoul National University Press.

Hirschl, Ran. 2005. The Question of Case Selection in Comparative Constitutional Law. American Journal of Comparative Law 53: 125-155.

Hyundai Asan. 2009. Hyundai Asan: Opening the Way. [Bilingual corporate website in Korean and English]. http://www.hyundai-asan.com/

Independent Commission on Decommissioning. 2005. Report of the Independent International Commission on Decommissioning, September 26, 2005.

2009. Report of the Independent International Commission on Decommissioning, September 4, 2009.

Jaung, Hoon. 2002. Political Process, Interest Groups and Korean Unification: With Some Implications from the German Experience in Constitutional Handbook on Korean Unification. Volume II: Political and Social Issues, eds. Sung-Hee Jwa et al. Seoul: Korea Economic Research Institute.

Jhe, Seong-Ho. 2004. Four Major Agreements on Inter-Korean Economic Cooperation: Legal Measures for Implementation. East Asian Review 16: 19-40. Kang, Grace M. 2006. A Case for the Prosecution of Kim Jong Il for Crimes against Humanity, Genocide, and War Crimes. Columbia Human Rights Law Review 38(1): 51-114.

Kang, Myoung-Kyu. 1990. Acknowledgements in Korea and Germany: Lessons in Division, eds. Myoung-Kyu Kang and Helmut Wagner. Seoul: Seoul National University Press.

Kee, Robert. 1972. The Green Flag: A History of Irish Nationalism. London: Weidenfeld and Nicolson.

Kim, Jasper S. and Brendan M. Howe. 2004. Pre-Emption Against Pyongyang: Is a Military Strike on the Korean Peninsula Legal? Journal of Korean Law 4(1): 123-154.

Kim, Kwang-Rok. 2003. Settling Business Disputes with North Koreans in the Advent of the External Economic Arbitration Law. Transnational Law 16(2): 401-410.

Kim, Kyong-Dong and On-Jook Lee. 2003. The Two Koreas: Social Change and National Integration. Seoul: Jimoondang.

Kim, Young-Ho. 2003. North Korean Negotiating Behavior and the Future of the Divided Korea in New International Order and Future of Divided Nations, eds. Hak-joon Kim and Gottfried Kindermann. Scoul: International Political Science Association Research Committee on System Integration of Divided Nations.

Kindermann, Gottfried-Karl. 2003. Political Lessons from Facts and Events Before and After German Reunification in New International Order and Future of Divided 
Nations, eds. Hak-joon Kim and Gottfried Kindermann. Seoul: International Political Science Association Research Committee on System Integration of Divided Nations.

Koh, B.C. 2002. From Confederation to Federation: Toward Unified Korea in Constitutional Handbook on Korean Unification. Volume III: Law Issues, eds. Sung-Hee Jwa et al. Seoul: Korea Economic Research Institute.

Kuechler, Manfred. 2002. Political Culture and Mass Sentiment in Constitutional Handbook on Korean Unification. Volume II: Political and Social Issues, eds. Sung-Hee Jwa et al. Seoul: Korea Economic Research Institute.

Lee, Eric Yong-Joong. 2004. The Six-Party Talks and the North Korean Nuclear

Dispute Resolution Under the IAEA Safeguards Regime. Asian-Pacific Law E Policy Journal 5: 101-123.

Lee, Kyu Chang. 2008. Protection of North Korean Defectors in China and the Convention against Torture. Regent Journal of International Law 6: 139-170. Lee, Myung Soo. 1994. Living Together on the Korean Peninsula. Seoul: Asiatic Research Center, Korea University.

Lee, Young-Sun. 2002. The Cost and Financing of Korean Unification in Constitutional Handbook on Korean Unification. Volume IV: Economic Issues, eds. Sung-Hee Jwa et al. Seoul: Korea Economic Research Institute.

Li, Sam Ro. 1993. The Reunification of Korea and Peace and Security in Asia in Korean Unification: Implications for Northeast Asia. Honolulu, HI: Pacific Forum/Centre for Strategic and International Studies.

Lim, Eul-chul. 2007. Kaesong Industrial Complex: History, Pending Issues, and Outlook. Seoul: Haenam Publishing Company.

Lim, Wonhyuk. 2009. Regional Multilateralism in Asia and the Korean Question. CNAPS Working Paper, Center for Northeast Asian Policy Studies, The Brookings Institution.

Lyou, Byung-Hwa. 1986. Peace and Unification in Korea and International Law. Baltimore, MD: University of Maryland School of Law.

Mason, David. 2009. San-shin Website. http://www.san-shin.org/

McGarry, John. 2001. Northern Ireland, Civic Nationalism, and the Good Friday Agreement in Nortbern Ireland and the Divided World: Post-Agreement Northern Ireland in Comparative Perspective, ed. John McGarry. Oxford: Oxford University Press.

Michelman, Frank I. 1999. Morality, Identity, and "Constitutional Patriotism." Denver University Law Review 76(4): 1009-1028.

Moon, Chung-in and Jeong-Ho Roh. 2002. Designing Constitutional Foundation for Korean Unification: An Overview in Constitutional Handbook on Korean Unification. Volume I: Introduction, eds. Sung-Hee Jwa et al. Seoul: Korea Economic Research Institute.

Moon, Chung-in and David I. Steinberg. 1999. Preface in Kim Dae-jung Government and Sunshine Policy: Promises and Challenges, eds. Chung-in Moon and David 
I. Steinberg. Seoul: Yonsei University Press.

Morgan, Austen. 2000. The Belfast Agreement: A Practical Legal Analysis. London: The Belfast Press.

Morgan, David Gwynn. 1997. The Separation of Powers in the Irish Constitution. Dublin: Round Hall.

Müller, Jan-Werner. 2006. On the Origins of Constitutional Patriotism. Contemporary Political Theory 5(3): 278-296.

. 2007. Three Objections to Constitutional Patriotism. Constellations: An

International Journal of Critical and Democratic Theory 14: 195-206.

Myers, Robert J. 2001. Korea in the Cross Currents: A Century of Struggle and the Crisis of Reunification. New York: Palgrave.

Nichol, Gene R. 2003. Toward a People's Constitution. California Law Review 91(2): 621-639.

Noland, Marcus. 2000. The Two Koreas: Prospects for Economic Cooperation and Integration. Honolulu, HI: East-West Center.

O'Donnell, Donal. 1999. Constitutional Background to and Aspects of the Good Friday Agreement-A Republic of Ireland Perspective. Northern Ireland Legal Quarterly 50(1): 76-89.

O'Leary, Brendan. 1999. The Nature of the Agreement. Fordham International Law Journal 22(4): 1628-1667.

Olsen, Edward A. 2005. Korea, The Divided Nation. Westport, CT: Praeger Security International.

Paige, Glenn D. 2008. Korean Leadership for Nonkilling East Asian Common Security in Northeast Asia and the Two Koreas: Metastability, Security, and Community, eds. Hyung-Kook Kim et al. Seoul: Yonsei University Press.

Paik, Nak-Chung. 1998. Habermas on National Unification in Germany and Korea in Habermas and the Korean Debate. Seoul: Seoul National University Press.

Park, Young-Kyu. 1993. Post-Unification Challenges in Korean Unification: Implications for Northeast Asia. Honolulu, HI: Pacific Forum/Centre for Strategic and International Studies.

Pfennig, Werner. 2001. The Rise and Fall of the Berlin Wall and the Korean DMZ in The Korean DMZ: Reverting beyond Division, ed. Chae-Han Kim. Seoul: Sowha.

Pile, Mathew W. 2001. Ten Years of Basic Law Amendments: Developing a Constitutional Model of German Unification. Vanderbilt Journal of Transnational Law 34: 635-680.

Powell, Jonathan. 2008. Great Hatred, Little Room: Making Peace in Northern Ireland. London: The Bodley Head.

Probert, Belinda. 1978. Beyond Orange and Green: The Political Economy of the Northern Ireland Crisis. London: Zed Press.

Rose, Richard. 1976. Northern Ireland: A Time of Cboice. London: Macmillan. 
Schnapper, Dominique. 1994. La communauté des citoyens: Sur lidée moderne de la nation. Paris: Gallimard.

UN. 2006. Press Release: United Nations Member States. ORG/1469. http://un.org

Waters, Christopher. 2006. Law in Places that Don't Exist. Denver University Journal of International Law and Policy 34(3): 401-423.

Wei, Yung. 2003. Chartering Peaceful Relations Between Taiwan and Mainland China: From Integration to Intra-National Commonwealth in New International Order and Future of Divided Nations, eds. Hak-joon Kim and Gottfried Kindermann. Seoul: International Political Science Association Research Committee on System Integration of Divided Nations.

Welsh, Helga A., Andreas Pickel, and Dorothy Rosenberg. 1997. East and West German Identities: United and Divided? in After Unity: Reconfiguring German Identities, ed. Konrad H. Jarausch. Providence, RI: Berghahn Books. Wijekoon, Lavanga V. 2008. Litigating Labor Rights Across a Demilitarized Zone: The South Korean Constitutional Court as a Forum to address Labor Violations in North Korea's Kaesong Special Economic Zone. Pacific Rim Law E Policy Journal 17(1): 265-294.

Wilford, Rick. 2001. Preface in Aspects of the Belfast Agreement. Oxford: Oxford University Press.

Yang, Sung Chul. 1999. The North and South Korean Political Systems: A Comparative Analysis, Rev. ed. Seoul: Hollym.

. 2002. The Implications of German Unification for Korea: Legal, Political, and International Dimensions in Korean Politics: Striving for Democracy and Unification, ed. Korean National Commission for UNESCO. Seoul: Hollym. Anthology of Korean Studies, Volume $\square$.

Yoon, Dae-Kyu. 2004. The Constitution of North Korea: Its Changes and Implications. Fordham International Law Journal 27(4): 1289-1305. 